UDC $616.361+616.24]-616.9092$

doi: https://doi.org/10.15407/ubj90.05.091

\title{
THE INDICES OF NITROGEN (II) OXIDE SYSTEM IN EXPERIMENTAL HEPATOPULMONARY SYNDROME
}

\author{
I. Ya. KRYNYTSKA, M. I. MARUSHCHAK \\ I. Horbachevsky Ternopil State Medical University, Ternopil, Ukraine; \\ e-mail: marushchak@tdmu.edu.ua
}

Hepatopulmonary syndrome (HPS) is a pulmonary complication of liver disease characterized by arterial hypoxemia. Altered nitrogen (II) oxide (NO) production has also been implicated in the pathogenesis of the HPS. The present study was designed to evaluate the indices of NO system in the blood serum and lung tissue of animals with different models of hepatopulmonary syndrome. The total NOS activity was performed by monitoring the rate of conversion of L-arginine into citrulline. The total contents of NO metabolites was assessed by evaluation of their amount, which included nitrite ions that were previously presented in the sample $\left(\mathrm{NO}_{2}^{-}\right)$and also nitrate ions reducted to nitrites $\left(\mathrm{NO}_{3}^{-}\right)$. We found a significant increase in total NOS activity in the lung tissue of Rats of both experimental groups as compared to control animals, but it was greater in the rats on the 28th day after the common bile duct ligation. The total concentration of $\mathrm{NO}_{2}^{-}+\mathrm{NO}_{3}^{-}$in the lung tissue of the rats in the experimental group $N 1$ also significantly increased (5.8 times) and in the rats of the experimental group with carbon -4.5 times $(P<0.001) v$ s the control group. Thus, in rats with different models of hepatopulmonary syndrome the activation of nitroxydergic process by a significant increase in nitrogen (II) oxide metabolites contents and total NO synthases activity has been established. Herewith a more pronounced intensification of nitroxydergic processes was observed in rats on the $28^{\text {th }}$ day after the common bile duct ligation.

Ke y w o r d s: nitrogen (II) oxide, NO-synthase, rats, hepatopulmonary syndrome.

$\mathrm{L}$ iver cirrhosis has emerged as a major cause of global health burden. According to the Global Burden of Disease 2010 study, liver cirrhosis caused 31 million Disability Adjusted Life Years (DALYs), or 1.2\% of global DALYs, in 2010, and one million deaths, or $2 \%$ of all deaths worldwide in that year [1]. In Ukraine the proportion of the deaths due to the digestive system disorders, which now occupy the fourth position in the structure of death causes, including $71.0 \%$ of patients with liver fibrosis and liver cirrhosis has also increased in recent years [2].

Hepatopulmonary syndrome (HPS) is a pulmonary complication of chronic liver disease characterized by arterial hypoxemia. This condition often manifests in adult patients with terminal liver disease, having a prevalence of 4 to 32\% [3]. By other data, the prevalence of HPS varies from 4 to $47 \%$, depending on the population and the criteria used to diagnose [4]. It is distinguished by three specific clinical entities consisting of liver disease and/or portal hypertension, disturbance of alveolar-arterial oxygen gradient $(>15 \mathrm{~mm} \mathrm{Hg}$ or $>20 \mathrm{mmHg}$ when age $\geq 65$ years), and intrapulmonary vascular dilatations (IPVD) [4, 5].

Patients with progressive HPS have respiratory symptoms including, shortness of breath, clubbed fingers, and cyanosis. Although it commonly occurs, shortness of breath is a nonspecific symptom of HPS. The most common manifestations of HPS are platypnea (increased shortness of breath when the body is in a vertical position) and orthodeoxia (3-10 mmHg reduction in $\mathrm{PaO}_{2}$ in capillary blood during transition from horizontal to vertical position) [6].

The pathogenesis of HPS is not completely understood, and no effective pharmacological treatment has been developed yet [7]. Without a liver trans-

(C) 2018 Krynytska I. Ya., Marushchak M.I. This is an open-access article distributed under the terms of the Creative Commons Attribution License, which permits unrestricted use, distribution, and reproduction in any medium, provided the original author and source are credited. 
plant the prognosis of HPS is poor. If HPS develops, the risk of death in the next year is about $41 \%$ [8].

Since the basis of HPS pathogenesis is the dilation of inner lung capillaries, researchers suggest that HPS is caused by the prolonged action of biologically active compounds on the blood vessels of pulmonary circuit. A possible role in resistant vasodilation have been suggested for many substances synthesized in the body. Potential mediators of HPS include: nitrogen (II) oxide, endothelin B and endothelin-1, prostaglandins E1 and I2, tumor necrosis factor $-\alpha$, vasoactive intestinal polypeptide, substance $\mathrm{P}$, calcitonin, glucagon, platelets activating factor, carbon monoxide and others [9].

The present study was, therefore, designed to evaluate the indices of nitrogen (II) oxide system in blood serum and lung tissue supernatant of animals with different models of hepatopulmonary syndrome.

\section{Materials and Methods}

The experiments were performed on 56 white nonlinear mature male rats, $180-220 \mathrm{~g}$ in weight that were housed at $25 \pm 3{ }^{\circ} \mathrm{C}$ and humidity of $55 \pm 2 \%$, under a constant $12 \mathrm{~h}$ light and dark cycle. Water was available ad libitum.

All experiments were conducted in accordance with the European Convention for the protection of vertebrate animals used for experimental and other scientific purposes [10].

The experimental animals were divided into the 4 groups: I - control group N $1(n=12)$; II - experimental group $\mathrm{N} 1(n=18)$; III - control group $\mathrm{N} 2(n=12) ; \mathrm{IV}-$ experimental group N $2(n=14)$.

The first experimental model of hepatopulmonary syndrome (HPS) was made by imposition of double ligature on common bile duct and its further dissection with a scalpel [11]. In the control group of animals N 1, the common bile duct was separated from the tissue, but not dissected. Postoperative wound was sewed up completely in layers. On the $28^{\text {th }}$ day after the surgery the animals were taken out of the experiment under thiopental anaesthesia.

The animals of the second experimental group were fed a mixture of maize flour, lard, cholesterol, and alcohol plus subcutaneous injection with carbon tetrachloride $\left(\mathrm{CCl}_{4}\right)$ oil solution for 8 weeks. The $\mathrm{CCl}_{4}$ oil solution $(400 \mathrm{~g} / \mathrm{l})$ was injected at $0.5 \mathrm{ml} / 100 \mathrm{~g}$ body weight on the first day of the experiment and at $0.3 \mathrm{ml} / 100 \mathrm{~g}$ body weight from the third day at an interval of two days until the experi- ment end. Lard was used only in the first two weeks accounting for $20 \%$ of the feed. Cholesterol was appended at $0.5 \%$ of feed for the whole experiment. Alcohol was used in the drinking water exclusively (300 ml/l) during the whole experiment [12].

The control group of animals N 2 was on a standard diet of the vivarium and was administered intragastrically the equivalent amount of olive oil. The main advantage of this model is its non-invasiveness and multifactoriality, which makes it closer to the real causes in patients.

During the simulation of the HPS 8 animals died.

NOS activity assay in the lung tissue supernatant was performed by monitoring the rate of conversion of L-arginine into citrulline [13]. Total protein was measured by Lowry assay [14].

Briefly, the samples aliquots that contained $300 \mathrm{mg}$ of protein were used to determine the total NOS activity. They were incubated for $60 \mathrm{~min}$ at $37^{\circ} \mathrm{C}$ in a total volume of $1 \mathrm{ml}$ substrate mixture ( $\mathrm{pH}$ 7.0) of the following composition ( $\mu \mathrm{mol} /$ $\mathrm{ml}): \mathrm{KH}_{2} \mathrm{PO}_{4}-50, \mathrm{MgCl}_{2}-1, \mathrm{CaCl}_{2}-2, \mathrm{NADPH}$ (Sigma, USA) - 1, L-arginine -2 . The reaction was stopped by adding $0.3 \mathrm{ml}$ of $\mathrm{HClO}_{4}\left(\mathrm{C}_{\mathrm{N}}=2 \mathrm{~mol} / \mathrm{l}\right)$. The samples that contained the full substrate mixture previously denatured by $\mathrm{HClO}_{4}\left(\mathrm{C}_{\mathrm{N}}=2 \mathrm{~mol} / \mathrm{l}\right)$ were used as a control. The mixture was centrifuged at $3500 \mathrm{~g}$ for $10 \mathrm{~min}$ and the non-protein supernatant mixtures were used to test L-citrulline by highly specific method for color reaction with antipyrine. Its sensitivity is $0.2 \mathrm{mg}$ of L-citrulline in $1 \mathrm{ml}$, so it can be used to study the NOS activity. Proteinfree aliquot samples were mixed with $2 \mathrm{ml}$ of reagent $(1 \mathrm{ml}$ of $59 \mathrm{mmol} / \mathrm{l}$ diacetyl monoxime (Sigma, USA) $+1 \mathrm{ml}$ of $32 \mathrm{mmol} / \mathrm{l}$ antipyrine (Sigma, USA) $+55 \mu \mathrm{mol} / \mathrm{l}$ Ferrous (II) sulphate in $\mathrm{H}_{2} \mathrm{SO}_{4}\left(\mathrm{C}_{\mathrm{N}}=6\right.$ $\mathrm{mol} / \mathrm{l})$ ) and boiled for $15 \mathrm{~min}$ in a water bath. After cooling the value of extinction was determined at $456 \mathrm{~nm}$. The citrulline content was determined using a calibration graph. Total NOS activity was expressed as pmol of L-citrulline/min per $1 \mathrm{mg}$ of protein.

Quantitative assessment of total concentration of $\mathrm{NO}_{2}^{-}+\mathrm{NO}_{3}^{-}$was performed by evaluation of their amount, which included nitrite ions that were previously presented in the sample $\left(\mathrm{NO}_{2}^{-}\right)$as well as nitrate ions reduced to nitrites $\left(\mathrm{NO}_{3}^{-}\right)^{-}$[15]. The reduction was performed using zinc dust in acidic environment. Nitrites with sulphanilic acid underwent a reaction of diazotisation. The obtained diazo- 
tisation compound with N-1-naphthtylethylendiamin formed the azo dye. Optical density of the obtained colour solution was evaluated by spectrophotometry at $536 \mathrm{~nm}$.

The total concentration of $\mathrm{NO}_{2}{ }^{-}+\mathrm{NO}_{3}{ }^{-}$in the studied sample was estimated by the equation: $\mathrm{X}=(\mathrm{Y}-\mathrm{A}) / \mathrm{B}$, where $\mathrm{X}-$ concentration of NO metabolites in $\mu \mathrm{mol} / \mathrm{l}$; $\mathrm{Y}$ - optical density of the studied sample; B - regression coefficient; A - intercept.

All the data were processed using the software package Statistica 6.1 for Windows. Intergroup comparisons were performed using Mann-WhitneyWilcoxon U test. The median (Me) and interquartile range (IQR [Q25-Q75]) were deduced. Differences with $P$-value $<0.05$ were considered as significant.

\section{Results and Discussion}

Total NOS enzymatic activity in the lung tissue supernatant of rats with HPS was significantly increased in both experimental groups as compared to control animals, but was greater in the rats of the first experimental group (on the $28^{\text {th }}$ day after the common bile duct ligation) (Table).

The total concentration of $\mathrm{NO}_{2}^{-}+\mathrm{NO}_{3}^{-}$in blood serum of the rats on the 28th day after the common bile duct ligation was significantly increased (3.9 times, $P<0.001$ ) vs control group N 1 . In the rats of the second experimental group (with carbon tetrachloride induced cirrhosis) the total concentration of $\mathrm{NO}_{2}{ }^{-}+\mathrm{NO}_{3}^{-}$in blood serum also significantly increased (3.1 times, $P<0.001$ ) vs control group N 2 .

A comparison of total concentration of $\mathrm{NO}_{2}{ }^{-}$ $+\mathrm{NO}_{3}{ }^{-}$in blood serum and lung tissue supernatant was of great importance. It was determined that NO production disorders took place unidirectionally towards the oxidative burst. Thus, the total concentration of $\mathrm{NO}_{2}^{-}+\mathrm{NO}_{3}^{-}$in lung tissue supernatant in the rats of the experimental group $\mathrm{N} 1$ also increased 5.8 times $(P<0.001)$ and in the rats of the experimental group $\mathrm{N} 2-4.5$ times $(P<0.001)$. When compared the total concentration of $\mathrm{NO}_{2}^{-}+\mathrm{NO}_{3}{ }^{-}$in 2 experimental models of HPS, its prevalence in rats on the $28^{\text {th }}$ day after the common bile duct ligation was determined.

Since nitrogen (II) oxide (NO) is recognized as one of the most powerful endogenous pulmonary vasodilators, it has been suggested as the most likely candidate not only for the hyperdynamic type of circulation in liver cirrhosis, but also for HPS [16].

Probably, the synthesis of nitric oxide in experimental hepatopulmonary syndrome increased due to the activation of inducible NO-synthase. As liver cirrhosis develops, blood stasis, swelling of the mucosa, decreased intestinal peristalsis and reduced secretion of bile, lead to bacterial overgrowth in the intestine lumen, especially of the Gram-negative bacteria and to overproduction of endotoxins. At the same time, disrupted mucosal barrier and dysfunc-

The indices of nitrogen (II) oxide system in blood serum and lung tissue supernatant of rats with hepatopulmonary syndrome, Me [Q25-Q75]

\begin{tabular}{|c|c|c|c|c|}
\hline Group of animals & $\begin{array}{l}\text { Control group } \\
\mathrm{N} 1(n=12)\end{array}$ & $\begin{array}{c}\text { Experimental } \\
\text { group N } 1(n=12)\end{array}$ & $\begin{array}{l}\text { Control group } \\
\text { N } 2(n=12)\end{array}$ & $\begin{array}{l}\text { Experimental group } \\
\text { N } 2(n=12)\end{array}$ \\
\hline \multicolumn{5}{|c|}{ Blood serum } \\
\hline $\mathrm{NO}_{2}^{-}+\mathrm{NO}_{3}^{-}, \mu \mathrm{mol} / \mathrm{l}$ & $\begin{array}{c}36.7 \\
{[32.8 ; 38.7]}\end{array}$ & $\begin{array}{c}143.4 \\
{[131.6 ; 152.8]} \\
P_{1}<0.001\end{array}$ & $\begin{array}{c}33.4 \\
{[29.7 ; 35.9]}\end{array}$ & $\begin{array}{c}104.2 \\
{[96.3 ; 109.1]} \\
P_{1}<0.001 ; P_{2}<0.05\end{array}$ \\
\hline \multicolumn{5}{|c|}{ Supernatant of lung tissue } \\
\hline $\mathrm{NO}_{2}^{-}+\mathrm{NO}_{3}^{-}, \mu \mathrm{mol} / \mathrm{l}$ & $\begin{array}{c}14.1 \\
{[11.5 ; 16.4]}\end{array}$ & $\begin{array}{c}81.7 \\
{[77.5 ; 83.4]} \\
P_{1}<0.001\end{array}$ & $\begin{array}{c}12.0 \\
{[10.8 ; 13.4]}\end{array}$ & $\begin{array}{c}54.7 \\
{[50.8 ; 57.3]} \\
P_{1}<0.001 ; P_{2}<0.05\end{array}$ \\
\hline $\begin{array}{l}\text { Total NOS, pmol of } \\
\text { L-citrulline/min per } \\
1 \text { mg of protein }\end{array}$ & $\begin{array}{c}46 \\
{[39 ; 52]}\end{array}$ & $\begin{array}{c}139 \\
{[117 ; 161]} \\
P_{1}<0.001\end{array}$ & $\begin{array}{c}51 \\
{[43 ; 58]}\end{array}$ & $\begin{array}{c}116 \\
{[101 ; 125]} \\
P_{1}<0.001 ; P_{2}<0.05\end{array}$ \\
\hline
\end{tabular}

Notes: $P_{1}-$ significant difference as compared to the control animals; $P_{2}-$ significant difference between experimental animals. 
tion in hepatocytes and Kupffer cells cause migration of intestinal organisms and endotoxins into the blood, causing bacteremia and intestinal endotoxemia. Endotoxins destroy mitochondria and lysosomes of intestinal epithelial cells, triggering cell autolysis. Ultimately, a vicious circle of intestinal endotoxemia and increased permeability of intestinal mucosa is created [9].

Zhang et al. showed a significant increase of endotoxins and TNF- $\alpha$ level in plasma and the increased number of Gram-negative microorganism colonies in rats with HPS that suggests that intestinal endotoxemia is indeed implicated in the molecular mechanisms of experimental HPS [17].

As a result of the appearance of portosystemic shunts and a decrease in the hepatic phagocytic capacity the lung filters the systemic blood to compensate the decrease in hepatic phagocytosis, and the increase in the lung phagocytic activity results in macrophage accumulation in the pulmonary endothelium [18].

So endotoxin induced activation of monocyte/ macrophagal system involves Kupffer cells, macrophages of the spleen, pulmonary intravascular macrophages and blood mononuclear cells [19], and inducible NO synthase is a key enzyme in the macrophage that is potently induced in response to proinflammatory stimuli.

Our findings of increased nitric oxide production in case of HPS coincide with the studies of other authors. A series of experimental studies investigated NO quantities in the context of liver cirrhosis and HPS. Fallon et al. have emphasised the role of NO in experimental models of liver cirrhosis, where overexpression of eNOS by pulmonary vessels causes the increased production of endothelin-1 (ET-1) by cholangiocytes, resulting in the increased expression of endothelin receptor type B to ET-1 at the level of pulmonary vessels, and increases synthesis of nitrogen (II) oxide [20].

The level of NO in exhaled air was elevated in patients with HPS, returning to normal 3 to 12 months after the liver transplantation [21, 22]. In a similar study, B. Degano et al. found that concentration of NO in exhaled air of patients with cirrhosis was three times higher than that in healthy persons [23].

Using flow cytometry, which allowed differentiating alveolar and bronchial origin of NO, it was determined that the increased formation of NO mainly took place in the alveoli [24]. Notably, the production of nitrogen (II) oxide by alveoli can play an important role in haemodynamic disturbances and changes in gas exchange in patients with cirrhosis. Thus, a direct corellation between the alveolar production of NO and hyperdynamic type of circulation was established [24]. Moreover, overexpression of both inducible and constitutional isoforms of NO-synthase in alveolar macrophages and pulmonary endothelial cells was observed in rats with experimental liver cirrhosis [25, 26].

While this pulmonary overexpression has not yet been found in patients with HPS, it probably occurs in most cases of HPS, at least in patients who have been successfully treated using inhibitors of nitrogen (II) oxide synthesis or its targets, the socalled secondary messengers of cyclic guanosine monophosphate. Several studies successfully used the following therapeutic approaches in patients with HPS: either intravenous introduction of methylene blue, which is the main inhibitor of NO molecular target, cyclic guanosine monophosphate or spraying with NO synthase inhibitor (N-nitro-L-arginine methyl ester) [27-29].

However, further studies showed, that NO concentration does not affect hyperdynamic circulation and the severity of liver damage in cirrhosis patients. Thus, methylene blue has improved arterial oxygenation, but only temporarily, while L-NAME had no effect on gas exchange in many patients with HPS [30].

There can be no doubt that the increased production of nitric oxide is an important factor underlying the molecular mechanisms that cause pulmonary vascular dilatations in the hepatopulmonary syndrome, but future research is required into the mediators of pulmonary vascular change in HPS in the hope of identifying a target for a potential medical therapy.

Thus, in rats with different models of hepatopulmonary syndrome activation of nitroxydergic process by a significant increase in total concentration of $\mathrm{NO}_{2}^{-}+\mathrm{NO}_{3}^{-}$and total $\mathrm{NO}$ synthases activity in blood serum and lung tissue supernatant has been established. Herewith a more pronounced intensification of nitroxydergic processes was observed in rats on the $28^{\text {th }}$ day after the common bile duct ligation. Comparing the total concentration of $\mathrm{NO}_{2}^{-}+$ $\mathrm{NO}_{3}{ }^{-}$in blood serum and lung tissue supernatant in both models of hepatopulmonary syndrome, we have found the synchronous development of nitroxydergic processes on systemic and local levels and predominance of nitrogen (II) oxide synthesis in lungs. 
Study limitation. There are some limitations in the present study. Firstly, this research was conducted only on a small size of rat population. It is therefore essential to validate our findings with greater sample sizes to determine the features of nitroxydergic processes. Secondly, the present study investigated only 2 experimental hepatopulmonary syndrome models, which do not reflect all real causes in patients.

Conflict of interest statement. The authors stated that they have no conflicts of interest regarding the publication of this article.

\section{ПОКАЗНИКИ СИСТЕМИ \\ НІТРОГЕН (II) ОКСИДУ ЗА УМОВИ ЕКСПЕРИМЕНТАЛЬНОГО ГЕПАТОПУЛЬМОНАЛЬНОГО СИНДРОМУ}

\section{I. Я. Кринищька, М. I. Марущак}
ДВНЗ «Тернопільський державний медичний університет ім. І. Я. Горбачевського», Тернопіль, Україна; e-mail: marushchak@tdmu.edu.ua

Гепатопульмональний синдром (ГПС) - це легеневе ускладнення захворювань печінки, що характеризується артеріальною гіпоксемією. Ймовірно, що зміна продукціїнітроген (II) оксиду також задіяна в патогенезі ГПС. Це дослідження було виконано для оцінки показників системи $\mathrm{NO}$ в сироватці крові та легеневій тканині тварин iз різними моделями ГПС. Загальна активність NOS визначалася шляхом моніторингу швидкості перетворення L-аргініну в цитрулін. Сумарний вміст метаболітів NO було встановлено шляхом оцінки їх кількості, яка включала як нітрит-іони, які попередньо були присутні в пробі $\left(\mathrm{NO}_{2}^{-}\right)$, так і відновлені до нітритів нітратіони $\left(\mathrm{NO}_{3}^{-}\right)$. Встановлено вірогідне збільшення загальної активності NOS у легеневій тканині щурів обох експериментальних груп відносно контрольних тварин 3 переважанням у щурів після перев'язки загальної жовчної протоки. Сумарний вміст метаболітів NO в легеневій тканині щурів експериментальної групи № 1 (на 28-й день після перев'язки загальної жовчної протоки) також вірогідно збільшився у 5,8 раза, а в щурів експериментальної групи № 2 (тетрахлорметаніндукований цироз) - у 4,5 раза $(P<0,001)$ порівняно 3 контрольною групою. Отже, в щурів із різними моделями ГПС встанов- лено активацію нітроксидергічних процесів за рахунок значного збільшення вмісту метаболітів нітроген (II) оксиду та загальної активності NOсинтаз. При цьому вираженішу інтенсифікацію нітроксидергічних процесів встановлено в щурів на 28-й день після перев'язки загальної жовчної протоки.

К л ю чов і слова: нітроген (II) оксид, $\mathrm{NO}$-синтаза, щури, гепатопульмональний синдром.

\section{ПОКАЗАТЕЛИ СИСТЕМЫ НИТРОГЕН (II) ОКСИДА В УСЛОВИЯХ ЭКСПЕРИМЕНТАЛЬНОГО ГЕПАТОПУЛЬМОНАЛЬНОГО СИНДРОМА}

\section{И. Я. Криницкая, М. И. Марущак}

\section{ГВУЗ «Тернопольский государственный медицинский университет}

им. И. Я. Горбачевского», Тернополь, Украина; e-mail:marushchak@tdmu.edu.ua

Гепатопульмональный синдром (ГПС) это легочное осложнение заболеваний печени, характеризующееся артериальной гипоксемией. Вероятно, что изменение продукции нитроген (II) оксида также задействовано в патогенезе ГПС. Данное исследование было выполнено для оценки показателей системы NO в сыворотке крови и легочной ткани животных с различными моделями ГПС. Общая активность NOS определялась путем мониторинга скорости превращения L-аргинина в цитруллин. Суммарное содержание метаболитов NO определялось путем оценки их количества, которая включала как нитрит-ионы, предварительно присутствующие в пробе $\left(\mathrm{NO}_{2}^{-}\right)$, так и восстановленные к нитритам нитрат-ионы $\left(\mathrm{NO}_{3}^{-}\right)$. Установлено достоверное увеличение общей активности NOS в легочной ткани крыс обеих экспериментальных групп относительно контрольных животных с преобладанием у крыс после перевязки общего желчного протока. Суммарное содержание метаболитов $\mathrm{NO}$ в легочной ткани крыс экспериментальной группы № 1 (на 28-й день после перевязки общего желчного протока) также достоверно увеличилось в 5,8 раза, а у крыс экспериментальной группы № 2 (тетрахлорметаниндуцированный цирроз $)$ в 4,5 раза $(P<0,001)$ по сравнению с 
контрольной группой. Таким образом, у крыс с различными моделями ГПС установлено активацию нитроксидэргических процессов за счет значительного увеличения содержания метаболитов нитроген (II) оксида и общей активности $\mathrm{NO}$-синтаз. При этом более выраженная интенсификация нитроксидэргических процессов установлена у крыс на 28-й день после перевязки общего желчного протока.

К л ю че вы е с лов ва: нитроген (II) оксид, NO-синтаза, крысы, гепатопульмональный синдром.

\section{References}

1. Mokdad AA, Lopez AD, Shahraz S, Lozano R, Mokdad AH, Stanaway J, Murray CJ, Naghavi M. Liver cirrhosis mortality in 187 countries between 1980 and 2010: a systematic analysis. BMC Med. 2014; 12: 145.

2. Abrahamovych O, Abrahamovych M, Tolopko S, Ferko M. Character and frequency of the variations of co- and polymorbid syntropic extrahepatic lesions and their dependence on the hepatopulmonary syndrome severity degree in cirrhotic patients. Georgian Med News. 2016; 11(260): 34-41.

3. Amin Z, Amin HZ, Tedyanto NM. Hepatopulmonary Syndrome: A Brief Review. Rom $J$ Intern Med. 2016; 54(2): 93-97.

4. Cosarderelioglu C, Cosar AM, Gurakar M, Dagher NN, Gurakar A. Hepatopulmonary Syndrome and Liver Transplantation: A Recent Review of the Literature. J Clin Transl Hepatol. 2016; 4(1): 47-53.

5. Rodríguez-Roisin R, Krowka MJ, Hervé P, Fallon MB. Pulmonary-Hepatic vascular Disorders (PHD). Eur Respir J. 2004; 24(5): 861880.

6. Krynytska I, Marushchak M, Mikolenko A, Bob A, Smachylo I, Radetska L, Sopel O. Differential diagnosis of hepatopulmonary syndrome (HPS): Portopulmonary hypertension (PPH) and hereditary hemorrhagic telangiectasia (HHT). Bosn J Basic Med Sci. 2017; 17(4): 276285.

7. Zhang J, Fallon MB. Hepatopulmonary syndrome: update on pathogenesis and clinical features. Nat Rev Gastroenterol Hepatol. 2012; 9(9): 539-549.

8. Ilchenko LYu, Fedorov IG, Karabinenko AA, OskanovaRS, Storozhakov GI. Hepatopulmonary syndrome: state of problem. Sovr Tekhnol Med. 2009; (1): 84-88.

9. Krynytska IYa, Marushchak MI, Klishch IM, Birchenko IV. Molecular mechanisms of hepatopulmonary syndrome. Fiziol Zh. 2017; 63(3): 90-102.

10. European convention for the protection of vertebrate animals used for experimental and other scientific purposes. Council of Europe. Strasbourg 1986; 123 : 52.

11. Fallon MB, Abrams GA, McGrath JW, Hou Z, Luo B. Common bile duct ligation in the rat: a model of intrapulmonary vasodilatation and hepatopulmonary syndrome. Am $J$ Physiol. 1997; 272(4 Pt 1): G779-G784.

12. Zhang HY, Han DW, Zhao ZF, Liu MS, Wu YJ, Chen XM, Ji C. Multiple pathogenic factorinduced complications of cirrhosis in rats: a new model of hepatopulmonary syndrome with intestinal endotoxemia. World J Gastroenterol. 2007; 13(25): 3500-3507.

13. Fafula RV, Iefremova UP, Onufrovych OK, Maksymyuk HV, Besedina AS, Nakonechnyi IA, Vorobets DZ, Vorobets ZD. Alterations in arginase-no-synthase system of spermatozoa in human subjects with different fertility potential. J Med Biochem. 2018; 37(2): 134-140.

14. Lowry OH, Rosebrough NJ, Farr AL, Randall RJ. Protein measurement with the Folin phenol reagent. J Biol Chem. 1951; 193(1): 265275.

15. Kozar VV, Kudrya MY, Ustenko NV, Nikishina LE, Kravchenko SV. Determination of the concentration of metabolites of nitric oxide in serum. Lab Diagnost. 2010; (3): 14-16. (In Ukrainian).

16. Dinh-Xuan AT, Naeije R. The hepatopulmonary syndrome: NO way out? Eur Respir J. 2004; 23(5):661-662.

17. Zhang HY, Han DW, Su AR, Zhang LT, Zhao ZF, Ji JQ, Li BH, Ji C. Intestinal endotoxemia plays a central role in development of hepatopulmonary syndrome in a cirrhotic rat model induced by multiple pathogenic factors. World $J$ Gastroenterol. 2007; 13(47): 6385-6395.

18. Bosco AD, Schedler FB, Colares JR, Dias AS, Marroni NP. Hepatopulmonary syndrome: oxidative stress and physical exercise. EMJ. 2017; 2(4): 69-75.

19. Gill SS, Suri SS, Janardhan KS, Caldwell S, Duke T, Singh B. Role of pulmonary 
intravascular macrophages in endotoxin-induced lung inflammation and mortality in a rat model. Respir Res. 2008; 9(1): 69.

20. Fallon MB. Mechanisms of pulmonary vascular complications of liver disease: hepatopulmonary syndrome. J Clin Gastroenterol. 2005; 39(4 Suppl 2): S138-S142.

21. Hamamoto J, Toba S, Hirosako S, Nakamura K, Fujii K, Kohrogi H. A case of hepatopulmonary syndrome with elevated exhaled nitric oxide. Nihon Kokyuki Gakkai Zasshi. 2010; 48(5): 379384.

22. Rolla G, Brussino L, Colagrande P, Scappaticci E, Morello M, Bergerone S, Ottobrelli A, Cerutti E, Polizzi S, Bucca C. Exhaled nitric oxide and impaired oxygenation in cirrhotic patients before and after liver transplantation. Ann Intern Med. 1998; 129(5): 375-378.

23. Degano B, Mittaine M, Hervé P, Rami J, Kamar N, Suc B, Rivière D, Rostaing L. Nitric oxide production by the alveolar compartment of the lungs in cirrhotic patients. Eur Respir J. 2009; 34(1): 138-144.

24. Delclaux C, Mahut B, Zerah-Lancner F, Delacourt C, Laoud S, Cherqui D, Duvoux C, Mallat A, Harf A. Increased nitric oxide output from alveolar origin during liver cirrhosis versus bronchial source during asthma. Am J Respir Crit Care Med. 2002; 165(3): 332-337.

25. Nunes H, Lebrec D, Mazmanian M, Capron F, Heller J, Tazi KA, Zerbib E, Dulmet E, Moreau R,
Dinh-Xuan AT, Simonneau G, Hervé P. Role of nitric oxide in hepatopulmonary syndrome in cirrhotic rats. Am J Respir Crit Care Med. 2001; 164(5): 879-885.

26. Zhang J, Ling Y, Luo B, Tang L, Ryter SW, Stockard CR, Grizzle WE, Fallon MB. Analysis of pulmonary heme oxygenase- 1 and nitric oxide synthase alterations in experimental hepatopulmonary syndrome. Gastroenterology. 2003; 125(5): 1441-1451.

27. Brussino L, Bucca C, Morello M, Scappaticci E, Mauro M, Rolla G. Effect on dyspnoea and hypoxaemia of inhaled $\mathrm{N}(\mathrm{G})$-nitro-L-arginine methyl ester in hepatopulmonary syndrome. Lancet. 2003; 362(9377): 43-44.

28. Aksu B, Umit H, Kanter M, Guzel A, Aktas C, Civelek S, Uzun H. Effects of methylene blue in reducing cholestatic oxidative stress and hepatic damage after bile-duct ligation in rats. Acta Histochem. 2010; 112(3): 259-269.

29. Schenk P, Madl C, Rezaie-Majd S, Lehr S, Müller C. Methylene blue improves the hepatopulmonary syndrome. Ann Intern Med. 2000; 133(9): 701-706.

30. Gómez FP, Barberà JA, Roca J, Burgos F, Gistau C, Rodríguez-Roisin R. Effects of nebulized $\mathrm{N}(\mathrm{G})$-nitro-L-arginine methyl ester in patients with hepatopulmonary syndrome. Hepatology. 2006; 43(5): 1084-1091.

Received 15.05.2018 